\title{
BROWNTOP SEED PRODUCTION: WEED COMPETITION EFFECTS AND HERBICIDE TOLERANCE
}

\author{
M.P. ROLSTON, W. ARCHIE and K. REDDY \\ AgResearch, PO Box 60, Lincoln
}

\begin{abstract}
In a browntop (Agrostsis capillirs syn. A. tenuis) crop, weeds reduced seed yields by up to $78 \%(485 \mathrm{~kg} / \mathrm{ha})$. When the weed mass contributed 10 to $50 \%$ of the dry matter, every $1 \%$ increase in weeds decreased seed yield by $9.4 \mathrm{~kg} / \mathrm{ha}$. The main weed species causing yield loss were broadleaved species. The two best herbicide treatments were a mixture of metsulfuron $3 \mathrm{~g} / \mathrm{ha}+$ mecoprop-bromoxynil-ioxynil 1035$225-225 \mathrm{~g} / \mathrm{ha}$; and a mixture of metsulfuron $3 \mathrm{~g} / \mathrm{ha}+$ triclopyr $180 \mathrm{~g} / \mathrm{ha}$. In a first year browntop crop seed yields were tolerant to metsulfuron $3 \mathrm{~g} / \mathrm{ha}$, tribenuron $22 \mathrm{~g} / \mathrm{ha}$, thifensulfuron $30 \mathrm{~g} / \mathrm{ha}$, and diflufenican + bromoxynil $75+750 \mathrm{~g} / \mathrm{ha}$.
\end{abstract}

Keywords: bentgrass, competition, herbicide, metsulfuron, seed yield.

\section{INTRODUCTION}

Browntop (Agrostsis capillirs syn. A. tenuis) for turf seed production in New Zealand, is grown on 500 ha with an annual production of 75 to 80 tonnes. New Zealand bred cultivars continue to be ranked in the top five in European turf trials. Weeds in browntop seed crops are competitive (Rolston and Hare 1986a and b), and lower seed quality with speedwell (Veronica spp.) being a common seed contaminant (W. Argyle, pers. comm.). A number of new herbicides have become available and farmers are using some of these, especially metsulfuron, on established crops. Browntop pastures have shown tolerance to metsulfuron at 18 to $100 \mathrm{~g} / \mathrm{ha}$ (Popay et al. 1985; Turner et al. 1986). However the tolerance of seedling, first year seed production stands, to these herbicides is unknown. The trials reported in this paper evaluated both the effects of weed competition and herbicide tolerance on browntop seed crops.

\section{Weed competition and control trial}

\section{MATERIAL AND METHODS}

The trial was sown on 15 March 1996 with browntop cv. "Grasslands Sefton" at the Lincoln University Henley Research Farm, Springs Road, Lincoln. Plots were 4m $\mathrm{x} 4 \mathrm{~m}$, with three replications in a randomized block design. Herbicides were applied on 17 June 1996, in 300 litres/ha water with the browntop at the 3 leaf stage (Freekes Growth Score 1), and $2 \mathrm{~cm}$ tall. The herbicides used were mecoprop + bromoxynil + ioxynil mixture (Axall), dicamba, diflufenican + bromoxynil (Jaguar), diuron (Karmex), ethofumesate (Nortron), fenoxyprop-P-ethyl(PumaS), metsulfuron(Escort), tribenuron (Granstar) and triclopyr (Grazon). Weeds present and stage of growth were; field pansy (Viola arvensis ) 3-4 leaf, spurrey (Spergula arvensis) 4-5 leaf, wire weed (Polygonum arviculara) 4-6 leaf, speedwell(Veronica sp.) 4 leaf, chickweed (Stellaria media) $10 \mathrm{~cm}$ diameter, calandrinia (Calandrinia spp.) 7-8 leaf, annual poa (Poa апnиа) 2-3 tillers and wild oat (Avena fatua) 4 tillers. Seed was harvested by cutting $1.0 \mathrm{~m}^{2}$ sample per plot, which was air dried in a hessian bag, before being threshed, cleaned and weighed to determine seed yield.

\section{Herbicide tolerance}

The browntop cv "Grasslands Egmont" was sown at $5 \mathrm{~kg} / \mathrm{ha}$ in $15 \mathrm{~cm}$ rows sown on the 16 February 1996 at the AgResearch Farm, Lincoln on a Wakanui silt loam soil. The trial was sown with an 'Oyjord' cone seeder, in four blocks $1.35 \mathrm{~m}$ (9 rows) by $43 \mathrm{~m}$ long. Each block was interspersed with other grass species. Herbicides used, 
application date in 1996, and the Freekes growth stage (GS) at treatment were: diflufenican + bromoxynil (18 April, GS 3); fenoxyprop-P-methyl (29 September GS 4-5); mecoprop-bromoxynil-ioxynil mixture (July, GS 3); tribenuron (11 September, GS 4); thifensulfuron (11 September, GS 4). Crop injury was evaluated by visual evaluation on 9 July, 21 days after treatment (DAT) and 27 September, 102 DAT.

In both trials the browntop crops received $150 \mathrm{~kg} \mathrm{~N} / \mathrm{ha}$ as urea and were sprayed with the fungicide tebuconazole at $190 \mathrm{~g} / \mathrm{h}$ a after head emergence. Seed was harvested by cutting a $1.0 \mathrm{~m}$ wide $\mathrm{x} 1.35 \mathrm{~m}$ long strip from each plot. The sample was air dried in a hessian bag, before being threshed, cleaned and weighed to determine seed yield.

\section{Weed competition and control}

\section{RESULTS AND DISCUSSION}

Weeds had a marked competitive effect on browntop seed yields (Figure 1), with yield declining $9.4 \mathrm{~kg} / \mathrm{ha}$ for every $1 \%$ increase in weed mass as a percentage of total dry matter in December. This compares with a $4.7 \mathrm{~kg} / \mathrm{ha}$ seed yield decline for every $1 \%$ in weed cover (visual observation) in August reported in a previous trial with browntop (Rolston and Hare 1986b). The main weeds were mostly broadleaf species (including shepherds purse (Capsella bursa-pastoris), field pansy, speedwell, wireweed and Calandrina) and a low level of Poa annua. This is in contrast to the trial reported by Rolston and Hare (1986b), which had a high proportion of $P$. аппиа.

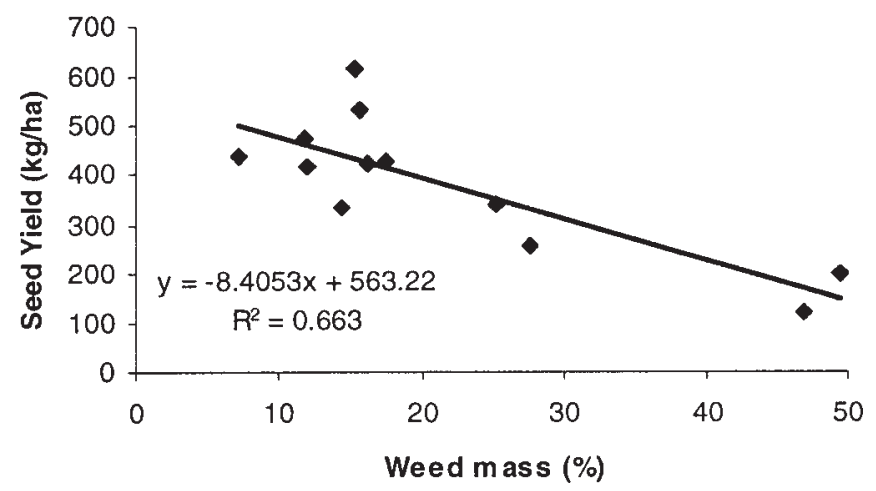

\section{FIGURE 1: Relationship between weed mass and seed yield in browntop.}

Increasing weed mass had a negative linear effect on browntop mass in December at flowering with a correlation of $\mathrm{R}^{2}=0.72$; while an increasing browntop mass was associated with a positive linear increase in seed yield (Figure 2). Thus the main effect of weed competition was to affect the browntop mass, and therefore the number of tillers to form seed heads.

The most effective treatments were combinations of metsulfuron $(3 \mathrm{~g} / \mathrm{ha})$ with either a mecoprop-bromxynil-ioxynil mixture or with triclopyr; the best treatment increased seed yields by $360 \%$, equal to $485 \mathrm{~kg}$ seed/ha (Table 1 ). With a grower's price of $\$ 6-50 / \mathrm{kg}$, this represents a $\$ 3150 /$ ha increase in gross revenue. The mean seed yield increase for 10 treatments was $292 \mathrm{~kg} / \mathrm{ha}$, worth $\$ 1890 / \mathrm{ha}$, or an average of $\$ 12$ return for every $\$ 1$ spent on weed control in seedling first year browntop seed crops. Any treatment that reduced the weed mass to under $18 \%$ of total herbage mass increased seed yields by at least $66 \%$ and in most cases more than doubled seed yield (Figure 1). Seedling browntop is tolerant to metsulfuron applied at $3 \mathrm{~g} / \mathrm{ha}$, a rate commonly used in established browntop. The level of weed control achieved with metsulfuron was enhanced by mixing with other herbicides, increasing seed yields by 26 to $46 \%$ compared with metsulfuron alone (Table 1). 


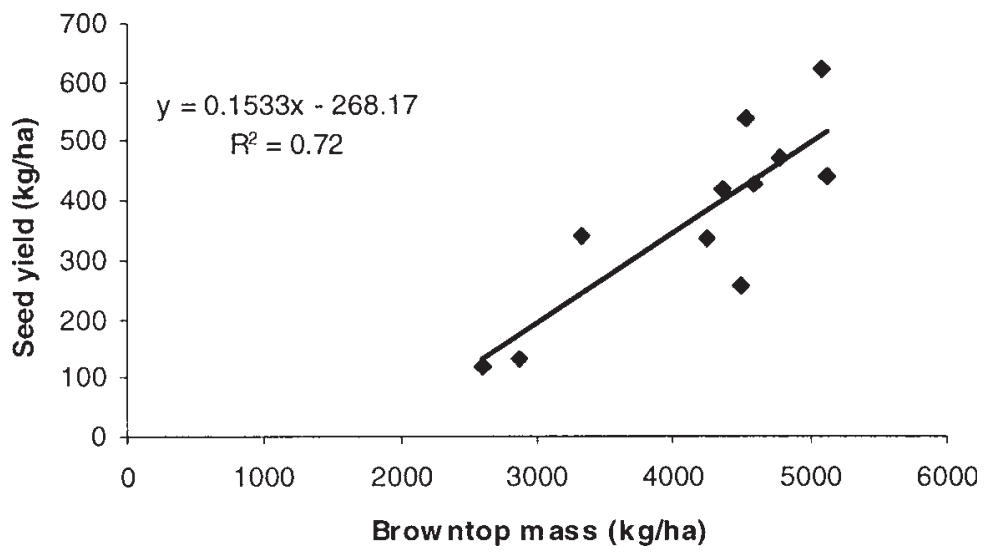

FIGURE 2: Relationship between browntop mass in December and seed yield.

TABLE 1: Browntop seed yields, crop injury and weed control from herbicide treatments.

\begin{tabular}{|c|c|c|c|c|c|c|c|}
\hline Herbicide & $\begin{array}{c}\text { Rate } \\
\text { (g ai/ha) }\end{array}$ & $\begin{array}{c}\text { Seed } \\
\text { yield } \\
(\mathrm{kg} / \mathrm{ha})\end{array}$ & $\begin{array}{l}\text { Seed } \\
\text { purity } \\
(\%)\end{array}$ & $\begin{array}{c}\text { Crop in } \\
21 \\
\mathrm{DAT}^{2}\end{array}$ & $\begin{array}{c}\text { jury } \% \\
102 \\
\text { DAT }\end{array}$ & $\begin{array}{c}\text { Weed } \\
\text { mass } \\
(\%)\end{array}$ & $\begin{array}{c}\text { Total } \\
\text { dry } \\
\text { matter } \\
(\mathrm{kg} / \mathrm{ha})\end{array}$ \\
\hline control & & 134 & 58.4 & 0 & 0 & 50 & 2860 \\
\hline $\mathrm{M}+\mathrm{B}+\mathrm{I}^{1}$ & $1035+225+225$ & 441 & 97.8 & 0 & 0 & 7 & 5110 \\
\hline dicamba & 400 & 337 & 98.0 & 0 & 0 & 25 & 3320 \\
\hline $\begin{array}{l}\text { metsulfuron } \\
\text { metsulfuron }\end{array}$ & 3 & 422 & 97.5 & 0 & 0 & 16 & 5600 \\
\hline $\begin{array}{r}+\mathrm{M}+\mathrm{B}+\mathrm{I} \\
\text { metsulfuron }\end{array}$ & $3+1035+225+225$ & 619 & 98.5 & 3 & 0 & 15 & 5090 \\
\hline+ triclopyr & $3+180$ & 535 & 99.2 & 0 & 0 & 16 & 4540 \\
\hline $\begin{array}{l}\text { tribenuron } \\
\text { diflufenican }\end{array}$ & 11 & 256 & 96.6 & 3 & 0 & 28 & 4490 \\
\hline + bromoxyni & $38+375$ & 334 & 98.9 & 0 & 0 & 14 & 4240 \\
\hline $\begin{array}{l}\text { ethofumesate } \\
\text { ethofumesate }\end{array}$ & 750 & 121 & 90.0 & 13 & 12 & 47 & 2600 \\
\hline $\begin{array}{l}\text { + diuron } \\
\text { ethofumesate }+\end{array}$ & $\begin{array}{r}750+1600 \\
+\quad\end{array}$ & 426 & 98.1 & 13 & 33 & 17 & 4580 \\
\hline $\begin{array}{c}\text { M+B+I } \\
\text { fenoxyprop + }\end{array}$ & $750+1035+225+225$ & 5473 & 97.5 & 43 & 8 & 12 & 4770 \\
\hline $\mathrm{M}+\mathrm{B}+\mathrm{I} \quad 1$ & $112+1035+225+225$ & 5420 & 97.6 & 20 & 0 & 12 & 4370 \\
\hline LSD $(\mathrm{P}<0.05)$ & & 286 & 25.7 & 14.7 & 12.5 & 23 & 1872 \\
\hline
\end{tabular}

${ }^{1} \mathrm{M}+\mathrm{B}+\mathrm{I}=$ mecoprop + bromoynil + ioxynil mixture

${ }^{2} \mathrm{DAT}=$ days after treatment

\section{Herbicide tolerance}

The seed yield of the untreated controls (Table 2) ranged from 340 to $480 \mathrm{~kg} / \mathrm{ha}$. The results are expressed as relative seed yields to allow easy comparison between herbicide blocks. Browntop showed good tolerance to all herbicides with no reduction in seed yield from any of the 12 herbicides evaluated (Table 1 and 2). Ethofumesate alone or in mixture and fenoxyprop mixed with mecoprop caused visual crop injury 
in the weed control trial (Table 1), but no crop injury was observed in the herbicide tolerance trial. Browntop had good tolerance to the commonly used broadleaf hormone mixture mecoprop + bromoxynil + ioxynil and diflufenican + bromoxynil (recently registered in ryegrass seed crops). Tribenuron, thifensulfuron and metsulfuron are low cost sulfonyl urea herbicides that show promise for use in browntop seed crops. Tribenuron has recently been registered for grass seed crops in Norway including bentgrass (Agrostis spp.) and in the USA in grass seed crops including ryegrass, tall fescue and cocksfoot (Rolston et al. 1997). Metsulfuron is being used by some growers in established (second year) browntop seed crops and the results of this trial suggests that it can be used in first year crops, but more work on rates and combinations is required.

TABLE 2: Relative seed yields of browntop in herbicide tolerance trial.

\begin{tabular}{lccc}
\hline Herbicide & $\begin{array}{c}\text { Rate } \\
(\mathrm{g} \text { ai/ha) }\end{array}$ & $\begin{array}{c}\text { Relative } \\
\text { seed yield }\end{array}$ & $\begin{array}{c}\text { Signif } \\
\text { LSD 5\% }\end{array}$ \\
\hline untreated & nil & 100 & \\
M+B+I & $2070+450+450$ & 98 & $\mathrm{NS}$ \\
metsulfuron & 3 & 94 & $\mathrm{NS}$ \\
tribenuron & 11 & 117 & $\mathrm{NS}$ \\
tribenuron & 22 & 130 & $\mathrm{NS}$ \\
thifensulfuron & 15 & 103 & $\mathrm{NS}$ \\
thifensulfuron & 30 & 106 & $\mathrm{NS}$ \\
diflufenican + bromoxynil & $75+750$ & 100 & $\mathrm{NS}$ \\
fenoxyprop & 56 & 117 & \\
\hline
\end{tabular}

\section{CONCLUSION}

First year browntop seed crops are very sensitive to competition, with large losses in potential yield if weeds are not controlled. Seed yields were increased by up to $360 \%$ when weeds were controlled with an early winter herbicide application. Metsulfuron has potential for use in browntop, and further work on rates, timing and mixtures are required.

\section{ACKNOWLEDGEMENTS}

The authors wish to acknowledge the following: Foundation for Research, Science and Technology for funding the weed competition trial; Foundation for Arable Research for funding the and herbicide tolerance trial; Agri-chemical companies for funding the provision of herbicides and Santosh Roy for technical assistance.

\section{REFERENCES}

Popay, A.I., Cornwell, M.J. and Rahman, A., 1985. Effects of metsulfuron-methyl on pasture. Proc. 38th N.Z. Weed and Pest Control Conf.: 102-105.

Rolston, M.P. and Hare, M.D., 1986a. Competitive effects of weeds on seed yields of first year grass seed crops. J. Applied Seed Prod. 4: 34-36.

Rolston, M.P. and Hare, M.D., 1986b. Herbicides for grass seed crops. 1. Seedling browntop, phalaris and tall fescue. Proc. 39th N.Z. Weed and Pest Control Conf.: 45-48.

Rolston, M.P.; Mueller-Warrant, G. and Aamlid, T. 1997. Use of tribenuron on grass seed crops. International Herbage Seed Production Research Group Newsletter 26: 2.

Turner, M.M., Iggo, G. and Meeklah, F.A., 1986. The effect of metsulfuron on sweet brier. Proc. 39th N.Z. Weed and Pest Control Conf.: 95-98. 